\title{
Dominance Relations in the Light of Repair- mechanisms in Family-doctor-Patient and Hospital Teacher-Student Encounters
}

\author{
Kránicz Rita, Hambuch Anikó, Hamar-Savay Judit, Rébék-Nagy G, Sárkány-Lőrinc Anita \\ Department of Languages for Specific Purposes, Faculty of Medicine, University of Pécs, Pécs, Hungary
}

\begin{abstract}
Introduction: Repair mechanisms, both marked and unmarked, are present in institutional interactions including family doctor-patient and hospital teacher-student encounters. While in most of the cases unmarked repair is carried out by the dominant partner, sometimes marked repair mechanisms are initiated by the client. The present study was undertaken to throw light upon these marked repairs. The aim of the study is to compare two interactions, the first is between a GP and a patient and the second is between a hospital teacher and a student.

Material and method: The dominance relations in the recorded and transcribed dialogues were shown as the first step in the investigation of the repairs. After realising typical repair mechanisms, the focus of the analysis is directed to special occasions, where the initiator is not the dominant participant.

Results: The doctor-patient relationship can be characterized by the dominance of the doctor and in the teacher-student encounter by the dominance of the teacher. Although in most of the cases the dominant participant initiates the turns, the initiation of the non-dominant party can also be observed, in 16-20 \% of the encounters.

Conclusions: The relatively frequent repairs of the non-dominant party suggests a diversion from the conventions of the institutional talk, which requires further investigation.
\end{abstract}

Keywords: doctor-patient relationship, hospital teacher, other-repair, self-initiated repair

Received: 16 May 2012

\section{Introduction}

The research focused on the conversation between a family doctor and a patient with heart disease. Furthermore, a hospital teacher's lesson with a sick child was analyzed with the method of conversation analysis (CA), which analyses institutional talks where the aims of the participants are more limited and institution specific.

During the comparison of institutional and colloquial conversations Heritage observes differences concerning first of all the turns, structural systems and the organization of sequences [1] mentioning also the studies on communication disturbances resulting from the asymmetry of the doctor-patient relationship [1]. Researching the dominance and asymmetry occurring in institutional talks Alexander Brock and Dorothee Meer point out that eventual authority relations leading to existing inequalities develop from various joint effects [2]. Analysing turns Hungarian research confirms the interactional presence of the dominance of the doctor [3] and the teacher [4] on the one hand, and the confidential relationship between the doctor and the patient and also the student and the teacher, on the other $[4,5]$.

CA puts the interactional meaning and the context in the focus, furthermore it deals with the process of verbalization and understanding as well [6]. The social context is

Correspondence to: Rita Kránicz

E-mail: rita.kranicz@aok.pte.hu formed dynamically that is expressed through the sequential structure of the interaction. The core of the interaction is the structure of the sequence. During both conversations the sequence is formed by interrogative pairs. Doctor-Patient dialogues in acute care have set structures [7]. Conversations include traces of the verbalization process that are interpreted either as natural signs or as mistakes. The latter should be corrected. The cause of mistake originates from potential disturbances of speech, understanding or the interaction mechanism [6], e.g. wrong articulation, sequence formation, syntax, mishearing, requestioning.

\section{Material and methods}

The corpus of the investigation is a written variation of a dialogue between a family doctor and a heart patient and a geography class between a hospital teacher and a student. The length of the recordings are 12 minutes and 31 minutes 32 " seconds.

The site of the recording of the doctor and a heart patient dialogue was in a family practice. Another patient was waiting for the doctor in the waiting room. The doctor's office is well equipped, pleasant place, where the doctor is sitting opposite the patient so as to establish a continuous eye contact with the patient as every word is of outstanding importance.

The recording was made by the hospital teacher at the Oncology Department of the Pediatric Clinics of Pécs University. The teaching was performed in a cosy furnished 
nice teaching room of the Pécs Hospital School which was established specifically for children receiving therapies. The student having received chemotherapy was facing the teacher.

The Ethical Committee allowed the examinations based on the written consent of the parents.

The first step of the analysis was the preparation of transcripts of the recorded dialogues by manual methods. This was followed by the identification of the repairs during the examination of turns. The application of the system of Schegloff aimed at the categorization of the repairs and the examination of the dialogues.

Based on this system we examined who initiated the repair (other-, or self-initiated repair) and who carried out the repair (actual speaker or other party) and finally who repaired whom (self-, or other-repair) and the outcome of the repair (successful or unsuccessful repair).

Based on the system of Schegloff we applied the following categories: self-initiated self-repair, other-initiated self-repair, self-initiated other-repair, other-initiated otherrepair, self-initiated unsuccessful-repair, other-initiated unsuccessful repair. The above categories are summarized in two tables, in which the repairs were registered.

\section{Results}

\section{The initiator of the repair}

Six repairs were examined in the doctor-heart patient dialogue. In the dialogue five times $(83 \%)$ the doctor initiated the repair. Once he repaired himself and three times (50\%)

Table I. Classification of repairs occurring during the lesson of a hospital teacher based on Schegloff categories

\begin{tabular}{|c|c|c|c|c|c|}
\hline $\begin{array}{l}\text { Number } \\
\text { of repair }\end{array}$ & $\begin{array}{l}\text { Type of } \\
\text { repair }\end{array}$ & Initiator & $\begin{array}{l}\text { Who } \\
\text { repairs }\end{array}$ & $\begin{array}{l}\text { Who will } \\
\text { be repaired }\end{array}$ & Cause of repair \\
\hline 1. & $+\mathrm{O}-\mathrm{S}$ & TEACHER & STUDENT & STUDENT & mistake of content \\
\hline 2. & + S-S & TEACHER & TEACHER & STUDENT & deficiency \\
\hline 3. & $+\mathrm{O}-\mathrm{S}$ & TEACHER & STUDENT & STUDENT & deficiency \\
\hline 4. & $+\mathrm{O}-\mathrm{S}$ & TEACHER & STUDENT & STUDENT & deficiency \\
\hline 5. & $+\mathrm{O}-\mathrm{S}$ & TEACHER & STUDENT & STUDENT & deficiency \\
\hline 6. & $+\mathrm{O}-\mathrm{O}$ & TEACHER & TEACHER & STUDENT & factual mistake \\
\hline 7. & $+\mathrm{O}-\mathrm{O}$ & TEACHER & TEACHER & STUDENT & factual mistake \\
\hline 8. & $+\mathrm{O}-\mathrm{O}$ & STUDENT & STUDENT & TEACHER & supplementation \\
\hline 9. & $+\mathrm{O}-\mathrm{O}$ & STUDENT & STUDENT & TEACHER & repair of content \\
\hline 10. & $+\mathrm{O}-\mathrm{O}$ & STUDENT & STUDENT & STUDENT & supplementation \\
\hline 11. & $+\mathrm{O}-\mathrm{O}$ & STUDENT & STUDENT & TEACHER & supplementation \\
\hline 12. & $+\mathrm{O}-\mathrm{O}$ & TEACHER & TEACHER & TEACHER & reinforcement \\
\hline 13. & $+\mathrm{O}-\mathrm{O}$ & TEACHER & TEACHER & STUDENT & supplementation \\
\hline 14. & $+S-S$ & TEACHER & TEACHER & TEACHER & factual mistake \\
\hline 15. & $+\mathrm{O}-\mathrm{O}$ & STUDENT & STUDENT & TEACHER & reinforcement \\
\hline 16. & $+\mathrm{O}-\mathrm{S}$ & TEACHER & STUDENT & STUDENT & lexical refinement \\
\hline 17. & $+\mathrm{O}-\mathrm{O}$ & TEACHER & TEACHER & STUDENT & factual mistake \\
\hline 18. & $+\mathrm{O}-\mathrm{O}$ & TEACHER & TEACHER & STUDENT & factual mistake \\
\hline 19. & $+\mathrm{O}-\mathrm{O}$ & TEACHER & TEACHER & STUDENT & factual mistake \\
\hline 20. & $+\mathrm{O}-\mathrm{O}$ & TEACHER & TEACHER & STUDENT & reinforcement \\
\hline
\end{tabular}

he repaired the patient. The patient initiated the repair of the doctor once. At the opening of the dialogue the doctor first corrected himself (16\%) as he did not address the patient by the name. On one occasion the patient complemented himself in reaction to the initiation by the doctor (Table II repair 4).

Twenty repairs were examined during the class of the hospital teacher. In the examined corpus fifteen times the teacher initiated the repair which agrees with the structure of a traditional lesson. On five occasions the student initiated the repair and in only one case he repaired himself and four times he repaired the teacher's utterance. The teacher is the one who corrected in more than fifty percent of the cases and the initiation of the student was fairly high.

\section{The cause of the repair}

As a cause of repair four cases were due to mistakes in the content or subject. In the examined lesson more than one third of the repairs were due to factual mistakes or mistakes of the content. Forty percent of the repairs were due to supplementing content or deficiency. Twenty percent of repairs were due to repairs supporting previous sentences. These repairs were meant to convince the speaker about understanding the other party correctly. It is interesting to note that it was the student rather than the teacher who wanted to check the understanding (repairs 8 and 15 in Table I).

\section{Outcome of the repairs}

It was found that the outcome of the repair process was successful, as five out of six repairs were made to set up the correct diagnosis. The only exception was the first repair which was a self-repair by the doctor.

An indispensible condition of the success of the lesson is the successful outcome of the repairs. In the conversation analyzed twenty examined repairs were of successful outcome regardless of the initiator, repairer and repaired party.

\section{Dominance relationships}

In the examined doctor-heart patient dialogue dominance relations suit the traditional doctor-patient paternal mod-

Table II. Classification of repairs occurring during doctor-heart patient dialogue based on Schegloff categories

\begin{tabular}{llllll}
\hline $\begin{array}{l}\text { Number } \\
\text { of repair }\end{array}$ & $\begin{array}{l}\text { Type of } \\
\text { repair }\end{array}$ & Initiator & $\begin{array}{l}\text { Who } \\
\text { repairs }\end{array}$ & $\begin{array}{l}\text { Who will } \\
\text { be repaired }\end{array}$ & Cause of repair \\
\hline 1. & - S-S & DOCTOR & DOCTOR & DOCTOR & factual mistake \\
2. & + O-O & DOCTOR & DOCTOR & PATIENT & factual mistake \\
3. & + O-S & DOCTOR & PATIENT & PATIENT & supplementation \\
4. & + O-O & DOCTOR & DOCTOR & PATIENT & reinforcement \\
5. & + O-O & PATIENT & PATIENT & DOCTOR & repair of content \\
6. & + O-S & DOCTOR & DOCTOR & PATIENT & reinforcement \\
\hline
\end{tabular}

Self-initiated self-repair (+ S-S) Other-initiated self-repair (+ O-S) Self-initiated other-repair $(+\mathrm{S}-\mathrm{O})$ Other-initiated other-repair: (+ O-O) Self-initiated unsuccessful repair: $(-S)$ Other-initiated unsuccessful repair: (-O) 
el. It means that it is the doctor who asks and the patient is the one who answers.

The dominance relationships were realised so that the teacher was the initiator and the student was the repaired party (see columns 2 and 4 in Table I). The teacher was the initiator in $75 \%$ of cases (column 2) and the student was the repaired party in $70 \%$ of the cases. It suits the traditional dominance relationships of a lesson.

\section{Repair processes which are not typical of the tradi- tional dominance relationships}

In the doctor-patient dialogue the patient repaired the doctor only once, which is not typical of the elderly patients. As the doctor had known his patient for many years and a confidential relationship developed between them. This difference causes no disturbance in the structure of the institutional talk and the patient does not complain.

The self-repair of the doctor was very unusual concerning both its content and place. When opening the dialogue the doctor addressed his patient by another name, which embarrassed him and made him apologize twice

In the repairs initiated by the student it was typical that he repaired the teacher (repairs 8, 9, 11 and 15 in Table I). It is interesting to examine this fact focusing on the student's motivation. In a traditional lesson it would be impolite. But the student may do this in this type of an informal lesson where the possibility of learning is a source of joy for both the teacher and the student as it reflects the satisfactory state of the student's health. The teacher's selfinitiated self-repair (2 times) can be regarded as an atypical example in the traditional lesson.

\section{Discussions}

By investigating the repairs the aim was to find the signs of the physician's or teacher's dominance in institutional talks as well as the different characteristics expected from asymmetric turns due to the special institutional background. These differences come from the personal style of conversations. The family doctor knows his patient well therefore they have got a personal relationship. This characterizes the hospital teacher's situation of as well, who often gives mental support to the child besides teaching. It can be concluded that both discourses suffer loss from the institutional character. The interactional structure and the relationship between the speakers formed unity, their separation was necessary for the purpose of the analysis. The institutionalism and the method of analysis became the common denominator of the analysis not mentioning that the institutional characteristics of both courses had been curtailed. Due to this fact it can be assumed that mistake repair in both conversations reflect the dominance relationship while special repairs can be found in the interactions where the repair was made by the non-dominant party [8].

\section{Conclusions}

During the analysis of mistakes we observed that, although they are most commonly non-syntactic by nature, during their repairs the syntactic structure applied can change. These changes can be the subject of further investigations.

\section{References}

1. Heritage J. Conversation analysis and institutional talk. In: Fitch KL, Sanders RE (eds.): Handbook of Language and Social Interaction. Psychology Press, 2004. http://www.gespreachsforschung-ozs.de/ heft2004/ga-brock.pdf

2. Brock A, Meer D. Macht-Hierarchie-Dominanz-A-/Symmetrie: Begriffliche Überlegungen zur kommunikativen Ungleichheit in institutionellen Gesprächen. Gesprächsforschung - Online-Zeitschrift zur verbalen Interaktion. 2004:184-209.

3. Hambuchné Kőhalmi A. „Akkor most meséljen arról, hogy van..." Orvosközpontú beszélgetésvezetés és/vagy laikus betegségelképzelések háziorvos - beteg konzultációkban. In: Silye M. (ed.): Porta Lingua-2011. A szaknyelvi kompetenciafejlesztéstől a munkaerőpiacig. SZOKOE, Debrecen, 2001:125-138.

4. Szabó Tamás P. Küljavítások a tanórán. In: Váradi T. (ed.): V. AlkNyelvdok Konferencia kötet. MTA Nyelvtudományi Intézet, Budapest, 2011:128139.

5. Sárkányné Lőrinc A. A beszélőváltás mechanizmusa háziorvosok szívbetegekkel folytatott beszélgetéseiben. In: Silye M. (ed.): Porta Lingua-2011. A szaknyelvi kompetenciafejlesztéstől a munkaerőpiacig. SZOKOE, Debrecen, 2011:181-186.

6. Iványi Zs. A nyelvészeti konverzációelemzés. Magyar Nyelvőr. 2001;125(1):74-93.

7. Byrne PS, Long B. Doctors talking to patients: A study of the verbal behaviours of doctors in the consultation. London: Her Majesty's Stationary Office, 1976

8. Kránicz R, Szántó-Csongor A, Hamar Sávay J, Rébék-Nagy G. Other initiated Repairs during Hospital Teachers' Tutorials. Acta Medica Marisiensis. 2011;56(6):597-600.

9. Schegloff Emanuel A, Jefferson G, Sacks $H$. The preference for selfcorrection in the organization of repair in conversation. Language. 1977;53(2):361-382. 